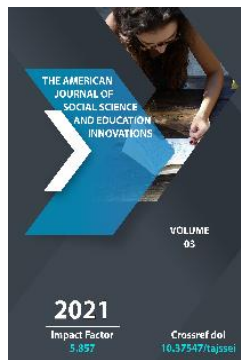

\title{
Some Issues Of Improving The Civil Service System In The Republic Of Uzbekistan
}

\author{
Rakhmonov Zafarjon Zayniddinovich, \\ Ministry Of Justice Of The Republic Of Uzbekistan Public Relations Department General \\ Counsel, Uzbekistan
}

Journal Website: http://usajournalshub.c om/index,php/tajssei

Copyright: Original content from this work may be used under the terms of the creative commons attributes 4.0 licence.

\section{ABSTRACT}

This article describes the civil service in the Republic of Uzbekistan, including the civil service system, regulatory documents, the need and importance of their improvement. At the same time, the article focuses on improving the procedure for admission, passage and termination of civil service, labor and responsibility of civil servants in general, reducing a number of legal gaps in the legislation on civil service, creating a transparent mechanism for admission and transition to the civil service, including the development of selection procedures, training and placement of modern and innovative personnel in the public service. In addition, proposals and recommendations have been developed to improve the civil service in the Republic of Uzbekistan.

\section{KEYWORDS}

Civil service, public civil service, transparent mechanism, “career model”, personnel reserve.

\section{INTRODUCTION}

In recent years, a wide range of reforms have been carried out in our country to improve the efficiency of the state management system.
The main goal is to create a completely new, effective and high-quality system of public administration, to ensure the proper 
functioning of public administration and local executive authorities. In turn, the achievement of this goal requires increasing the efficiency of the civil service, improving the legal status of civil servants.

Taking into account the importance of this issue, the president of the Republic of Uzbekistan Shavkat Mirziyoyev paid attention to precisely determining the legal status of the civil service, including civil servants, in his preelection program as a candidate for the presidency. In other words, in his speech at the VIII Congress of the Movement of Entrepreneurs and Businessmen - Liberal Democratic Party of Uzbekistan on October 19, 2016, it is no secret that despite the great responsibility of many civil servants, their working days and working week are not clearly defined. World experience shows that before making high demands on civil servants, it is necessary to strengthen their rights with a system of guarantee and protection. It is time to adopt a law on the civil service, taking into account the extreme urgency of the issue, it was argued that [1].

At the same time, the analysis conducted today on the civil service in our country, in particular on the civil service in the state, has shown that there are a number of shortcomings and problems, in particular:

- The existence of a number of legal gaps in the Constitution, Codes, laws and other normative legal acts of the Republic of Uzbekistan on the organization of the civil service, labor and liability of civil servants, in general, the legislation on civil service;

- Organization and management of the civil service of the state, access to the civil service of the state, transition to the civil service of the state, the order of exit of the civil service of the state are not systematically established;

- The need to improve the system of selection, preparation and placement of new-thinking personnel meeting the modern requirements of the civil service.

In this regard, a number of important legislative acts were adopted in order to improve the public service, in particular, the civil service of the state, while adapting it to modern requirements, in order to revise it.

In particular, in the decree of the president of the Republic of Uzbekistan № PF-4947 “On the strategy of actions for the further development of the Republic of Uzbekistan"on February 7, 2017, reform of the system of Public Service was established as one of the priority directions of improving the system of state and society construction [2].

Also, the 6th priority direction of the "concept of administrative reforms in the Republic of Uzbekistan"approved by the decree of the president of the Republic of Uzbekistan dated September 8, 2017 № PF-5185 has been defined as the formation of an effective system of professional public service.

In it, the organization of public service with the aim of creating a professional body of civil servants, including the development of projects of normative-legal documents regulating the issues of legal status, classification of civil servants, transparent rules of admission to the service (on a competitive basis), formation of personnel reserves, maintenance of the service, observance of moral norms, in addition to, Under the president of the Republic of Uzbekistan, the tasks of creating a specialized body responsible 
for the implementation of a single state personnel policy were envisaged.

As a result, in the decree of the president of the Republic of Uzbekistan

№ PF-4947 "on the strategy of actions for the further development of the Republic of Uzbekistan"on February 7, 2017, reform of the system of public service as one of the priority directions of improvement of the system of state and social construction was determined [3].

In addition, it is not surprising that the 6th priority direction of the "concept of Administrative Reforms in the Republic of Uzbekistan", approved by the decree of the president of the Republic of Uzbekistan № PF5185, adopted on September 8, 2017, is precisely the formation and designation of an effective system of professional public service. This document sets out the organization of public service, including their legal status, classification, transparent rules of admission to service, formation of personnel Reserve, passing the service, development of legislative documents regulating compliance with the norms of morality. In this direction, the duties of the president of the Republic of Uzbekistan for the organization of specialized bodies responsible for the implementation of the unified state personnel policy were also stipulated.

In this direction, the duties of the president of the Republic of Uzbekistan for the organization of specialized bodies responsible for the implementation of the unified state personnel policy were also stipulated.

According to the decree of the President of the Republic of Uzbekistan "On measures to radically improve the personnel policy and the system of the state civil service in the Republic of Uzbekistan" № PF-5843 and "On measures to organize the activities of the Agency for Civil Service Development under the President of the Republic of Uzbekistan" No. PQ-4472 a specialized body responsible for the implementation of a single state personnel policy was established [4].

In general, it is important to improve the legal framework of the state civil service in the Republic of Uzbekistan, as well as to establish procedures for admission, transition and exit to the state civil service. In this respect, the study of the practice of developed foreign countries is also of great importance.

In particular, the organization of Public Service in the United States of America is the product of the political system, with its specificity, which is distinguished from the civil service of other countries in the world.

In the USA, the modern civil service law on civil service, adopted in 1883 year, is called the Pendlton act, in which it is established that before the appointment of a civil servant, it is necessary to pass examinations in the specialty. In addition, on the basis of this law, a single system of public positions and salaries is established [5].

In Great Britain, however, the public service is also referred to as the "civil service". In this state, all officials are divided into two categories, that is, politicians who share the resignation of the government and administrators who are constantly hired by the Civil Service Commission, which is independent of other administrative bodies [6].

Officials of the civil service in Germany are divided into 4 degrees. These are small, medium, large and high. After the 
identification of the person of the candidate to be appointed to the career, this person must pass the probationary period. It is enough to have a document on the completion of a general education or vocational school for the candidate who is calling for a career at the first and second levels to participate in the competitions. An important role is given to the training and retraining of the country's civil service and other leadership before the selection of personnel [7].

We have already learned a little about the experience of some developed countries in the field of civil service.

Another important feature is the need to develop a transparent and fair understanding of access to the civil service in the Republic of Uzbekistan and the rise in career prospects. Because not a single legislative act provides for the entry into the service of a civil servant of the state, at the same time the exact procedure for the upsurge through his career is not established. Sometimes the employee who has worked well and the employee who has not worked well will also rise to the top. Therefore, it is necessary to introduce the principle of meritocracy and the "career model"in the system in order to create a transparent mechanism for entering the Civil Service and moving in career.

For the first time, the concept of meritocracy was described in the book "Rise of meritocracy", published in 1958 year by the British sociologist and politician Michael Yang [8]. Initially, this concept was closer to politics than management in terms of meaning, nevertheless, this term has become one of the most used concepts in the field of management today. According to him, meritocracy is a system in which abilities and achievements, regardless of their social origin, social status, wealth or power, are the basis for individuals to rise to the top [9].

The career model "Springboard" is common among managers and professionals.

Along with the fact that the potential, knowledge, experience and skills of the employee gradually increase, his position also gradually increases. Together with the position, the salary of the employee also increases, at a certain stage, he occupies the highest position for himself and tries to hold this position for a long time. Then he jumps out from the trampling and goes out to pension.

In place of the conclusion, it should be noted that today it is desirable to carry out the following procedures for improving the procedures for entering, passing and ending the civil service, as well as carrying out service activities in the civil service of the state:

First of all, the norms of the state civil service in the Republic of Uzbekistan are fixed in the Constitution, some codes, sectoral laws and other normative-legal acts;

Secondly, it will also require improvement of the processes of training and reserve formation, retraining and professional development of civil servants and management personnel;

Third, the principle of meritocracy and the "career model"should be introduced in the system in order to create a transparent mechanism for entering the Civil Service and moving in career;

Fourth, it is necessary to improve the system of training, retraining and reserve formation of civil servants. 
In particular, it is proposed to improve the activities of higher education institutions on the training of civil servants, including the introduction of civil service disciplines into the educational programs of most universities as a competitive science.

Implementation of the above proposals on the basis of a clearly defined system will contribute to the organizational and legal strengthening of the civil service in the Republic of Uzbekistan, adaptation to the world experience and creation of a reserve of qualified and mature personnel.

\section{REFERENCES}

1. Демократик ислохотларни изчил давом эттириш, халқимиз учун тинч ва осойишта, муносиб хаёт даражасини яратиш - барқарор тараққиёт кафолатидир. Ўзбекистон Республикаси Президентлигига номзод Шавкат Мирзиёевнинг Тадбиркорлар ва ишбилармонлар харакати - Ўзбекистон Либералдемократик партиясининг VIII съездидаги маърузаси. // https://uz.fundamentaleconomic.uz/?page_id=1132.

2. Ўзбекистон Республикаси Президентининг Фармони. Ўзбекистон Республикасини янада ривожлантириш бўйича Харакатлар стратегияси тўғрисида. // http://lex.uz/docs/3107036.

3. Ўзбекистон Республикаси Президентининг Фармони. Ўзбекистон Республикасини янада ривожлантириш бўйича Харакатлар стратегияси тўғрисида. // http://lex.uz/docs/3107036.
4. Ўзбекистон

Республикаси Президентининг қарори. Ўзбекистон Республикаси Президенти хузуридаги Давлат хизматини ривожлантириш агентлиги фаолиятини ташкил этиш чоратадбирлари тўғрисида //http://lex.uz/docs/4552053 .

5. Transcript of Pendleton Act (1883). //https://www.ourdocuments.gov/doc. php?flash $=$ false $\&$ doc $=48 \&$ page $=$ transc ript.

6. Civil Servants - Grades \& Roles. //https://www.civilservant.org.uk/infor mation-grades_and_roles.html.

7. Archive: Public employment - France. //https://ec.europa.eu/eurostat/statisti cs-explained/index.php?title= Archive:Public_employment__France\&oldid=369054.

8. Appiah KA. The myth of meritocracy: who really gets what they deserve? // https://www.theguardian.com/news/2 018/oct/19/the-myth-of-meritocracywho-really-gets-what-they-deserve.

9. Simard C. Is Your Company a Meritocracy? // https://www.fastcompany.com/111857 5/your-company-meritocracy. 